\title{
ECONOMIC EFFICIENCY OF COMPLEX MINERAL AND VITAMIN FEED SUPPLEMENT «NADEZHDA» IN THE DIET OF CALVES
}

Key words: feed supplement; natural zeolite; sapropel; young cattle; gross growth; cost; profit; profitability of cultivation.

\section{Authors' personal details}

1. Sabitov Munir, Candidate of Agricultural Sciences, head of the Department of animal husbandry, senior researcher, Bashkir Scientific Research Institute of Ufa Federal Research Center of the Russian Academy of Sciences, 450059, Republic of Bashkortostan, Ufa, R. Sorge str., 19, phone: +7 (347) 224-07-08, e-mail: malikowa1941@yandex.ru.

2. Farkhutdinova Albina, veterinarian of the Department of animal husbandry, Bashkir Scientific Research Institute of Ufa Federal Research Center of the Russian Academy of Sciences, 450059, Republic of Bashkortostan, Ufa, R. Sorge str., 19, phone: +7 (347) 224-07-08, e-mail: alfarhutdinova1984@yandex.ru.

3. Farkhutdinov Ildar, Candidate of Technical Sciences, associate professor of the department of Road Construction, Municipal and Agricultural Machines, Federal State Budgetary Educational Institution of Higher Education «Bashkir State Agrarian University», 450001, Ufa, 50-letiya Oktyabrya St., 34, e-mail: ildar1702@ mail.ru.

4. Malikova Maryam, Doctor of Agricultural Sciences, Professor, chief researcher of the Department of animal husbandry, Bashkir Scientific Research Institute of Ufa Federal Research Center of the Russian Academy of Sciences, 450059, Republic of Bashkortostan, Ufa, R. Sorge str., 19, phone: +7 (347) 224-07-08, e-mail: malikowa1941@yandex.ru.

The expediency of using the complex mineral and vitamin feed supplement «Nadezhda» (CMVFS) in the diets of calves of black-and-white breed has been studied and scientifically substantiated. CMVFS is a feed supplement containing in its composition such components as natural zeolite, sapropel, fluorinated phosphate, feed chalk, feed sulfur, magnesite, table salt, salts of macro-and microelements, vitamins - A, D, E. Before setting the animals on the experiment, their fodder base and its chemical composition used on the farm were studied. The feeds were low in calcium, phosphorus, magnesium, sulfur, manganese, copper, zinc and cobalt. At the same time, the ratio of nutrients and minerals, the degree of their availability for assimilation by the body does not provide their need. In

(C) Сабитов М.Т., Фархутдинова А.Р., Фархутдинов И.М., Маликова М.Г. experimental studies conducted on four similar groups of calves (10 heads each), the influence of inclusion of CMVFS in their diet according to the recipe No. 1, No. 2 and No. 3 was studied and the economic efficiency of their feeding was calculated. The influence of such feeding of calves on gross and average daily gain of live weight is found out. The economic calculations established that the profitability of growing calves receiving feeding recipe No. 1, in comparison with the animals of the control group receiving separate mineral supplements (salt, chalk aft), increased $4,40 \%$; the recipe № 2 $6,20 \%$, the recipe No. $3-10,24 \%$. Therefore, the most effective was a complex mineral and vitamin feed supplement, made according to the recipe number 3 .

УДК 619:616-053:616-008

DOI: $10.31563 / 1684-7628-2020-53-1-110-114$

Д.И. Синельщикова, Л.В. Клетикова, А.Н. Мартынов

\section{ИОННЫЙ СОСТАВ КРОВИ ТЕЛЯТ ПРИ АНТЕ- И НЕОНАТАЛЬНОМ ВВЕДЕНИИ БИОЛОГИЧЕСКИ АКТИВНОЙ ДОБАВКИ}

\footnotetext{
Ключевые слова: телята; гомеостаз; ионы; биологически активная добавка; антенатальное и неонатальное введение.
}

Введение. Постоянный режим внутренней среды обеспечивает функционирование организма как единой биологической системы 「11; 13]. Сохранение гомеостаза основано на потреб- лении и выведении воды и минеральных солей, где основными катионами выступают натрий, калий, кальций и магний, а анионами - хлор и фосфаты. 
Ионы натрия определяют объем внеклеточной жидкости, включая циркулирующую и депонированную кровь, лимфу, ликвор, желудочный и кишечный сок, жидкости серозных полостей [15]. Калий в свою очередь определяет биоэлектрическую активность клеток, формирование клеточных потенциалов действия и поддержание нервно-мышечной возбудимости и проводимости [2]. Кальций обеспечивает необходимую степень возбудимости нервной и мышечной ткани, участвует в свертывании крови [14]. Будучи кофактором множества ферментов, магний имеет отношение более чем к 300 биохимическим реакциям. Он необходим для нормального функционирования натрий-калий-АТФазного и кальций-АТФазного насосов. Соотношение внутриклеточного Са и $\mathrm{Mg}$ определяет внутриклеточный гомеостаз и антиоксидантную защиту клетки $[1 ; 3]$. В то же время все виды обмена в организме неразрывно связаны с превращением фосфорной кислоты, благодаря фосфорилированию осуществляется кишечная адсорбция, гликолиз, прямое окисление углеводов, транспорт липидов, обмен аминокислот и т. д. [9]. Хлор активизирует фермент амилазу, участвует в синтезе соляной кислоты, улучшает работу печени, обеспечивает постоянство осмотического давления, поддерживает нормальное артериальное давление, содействует выведению мочевины [12]. Все ионы входят в состав костной ткани. Недостаток натрия и хлора вызывает потерю аппетита и задержку роста у молодых животных. Продолжительная кальциемия приводит к остеопорозу, остеомаляции и родильному парезу у коров. Гипокалиемия сопровождается миопатией, фатальным проявлением которой является рабдомиолиз. Снижение энергетического потенциала и продуктивности возникают при нехватке фосфатов. Дефицит магния сочетается с другими состояниями ионной недостаточности $[4 ; 7 ; 8]$.

Исходя из важности электролитов для организма животных и особенно молодняка, целью настоящего исследования было изучение влияния биологически активной добавки, примененной в анте- и неонатальный период, на содержание ионов в крови у телят.

Условия, материалы и методы исследования. Для достижения цели сформировали 2 группы коров костромской породы в возрасте 3 4 лет. Первая группа (n=10) служила контролем и получала стандартный рацион, принятый в хозяйстве [10], вторая - опытная группа $(\mathrm{n}=20)$ получала к основному рациону добавку, содержащую низкомолекулярные пептиды, нуклеозиды и нуклеотиды в дозе 0,1 г/кг живой массы, один раз в день в течение пяти суток до отела.

У всех телят, полученных от экспериментальных коров, до первой выпойки молозива от- бирали пробы крови из яремной вены и анализировали содержание ионов $\mathrm{Na}, \mathrm{Cl}, \mathrm{K}, \mathrm{P}, \mathrm{Ca}$ и $\mathrm{Mg}$.

Затем сформировали три группы телят. Контролем служили телята, полученные от первой группы коров $(\mathrm{n}=10)$. Опытные группы телят, вторую и третью, сформировали от коров второй группы, получившей биологически активную добавку. Вторая группа телят $(\mathrm{n}=10)$ получала в течение молозивного периода 1 раз в день биологически активную добавку в дозе 0,1 г/кг живой массы. Третья группа $(\mathrm{n}=10)$, как и первая, в течение обозначенного периода получала молозиво согласно схеме выпойки. После окончания молозивного периода (5 дней) у телят повторно провели оценку ионного состава крови.

Эксперимент проведен в течение летнего и раннего осеннего периодов. Коровы и телята содержались в одинаковых условиях. Клинический осмотр животных, включенных в эксперимент, проводили дважды в день.

Лабораторные исследования выполнены на кафедре акушерства, хирургии и незаразных болезней животных Ивановской ГСХА. Сыворотку крови телят исследовали в течение 2-3 часов после взятия на биохимическом анализаторе BA-88A «Semi-auto Chemistry Analyzer» и анализаторе электролитов i-SMART 30 Vet. Биометрическую обработку результатов проводили с помощью табличного процессора Excel.

Результаты исследования. Анализ ионов в сыворотке крови новорожденных телят выявил тенденцию к повышению натрия, хлора, кальция и магния и снижение калия и фосфора в опытных группах, где в период внутриутробного развития коровам-матерям вводили дополнительно к основному рациону биологически активную добавку. Известно, что примененная добавка содержит низкомолекулярные пептиды, нуклеозиды и нуклеотиды, которые при дефиците питательных веществ в клетке способствуют синтезу адаптивных ферментов и внутриклеточных вторичных посредников индуцирующих сложный, согласованный каскад биохимических реакций, необходимый для усвоения поступившего корма и поддержания, таким образом, гомеостаза.

В результате у новорожденных телят опытных групп соотношение натрия и хлора, натрия и калия, калия и магния, кальция и фосфора составило $1,4: 1 ; 24,7: 1 ; 5,9: 1$ и $1,37: 1$ соответственно, тогда как в контрольной группе пропорция несколько иная: $1,3: 1 ; 22,6: 1 ; 6,6: 1$ и $0,87: 1$ (таблица). Изменение соотношения ионов приводит к изменению $\mathrm{pH}$ крови, нарушению реабсорбции веществ в почках, вызывает конформационные изменения белка [6]. Недостаточность буферных систем крови у новорожденных, обусловленная ионным дефицитом, может привести к развитию метаболического ацидоза. 
Таблица Содержание ионов в сыворотке крови телят, ммоль/л, $\mathrm{M} \pm \mathrm{m}, \mathrm{n}=10$

\begin{tabular}{|c|c|c|c|c|c|c|}
\hline \multirow{2}{*}{ Ионы } & \multicolumn{3}{|c|}{ Новорожденные телята } & \multicolumn{3}{c|}{ Телята 5-суточного возраста } \\
\cline { 2 - 7 } & 1 группа & 2 группа & 3 группа & 1 группа & 2 группа & 3 группа \\
\hline $\mathrm{Na}$ & $131,27 \pm 2,06$ & $137,33 \pm 0,47$ & $136,88 \pm 0,34$ & $108,17 \pm 1,27^{* *}$ & $138,20 \pm 0,41$ & $135,25 \pm 0,31$ \\
\hline $\mathrm{Cl}$ & $96,48 \pm 1,31$ & $99,53 \pm 0,73$ & $100,13 \pm 0,94$ & $80,48 \pm 0,47^{* *}$ & $106,37 \pm 0,83^{* *}$ & $97,15 \pm 0,77$ \\
\hline $\mathrm{K}$ & $5,80 \pm 0,06$ & $5,54 \pm 0,07$ & $5,50 \pm 0,02$ & $3,38 \pm 0,12^{* *}$ & $4,70 \pm 0,05^{* *}$ & $5,78 \pm 0,09^{*}$ \\
\hline $\mathrm{Ca}$ & $2,13 \pm 0,06$ & $2,23 \pm 0,08$ & $2,35 \pm 0,06$ & $2,00 \pm 0,04^{*}$ & $2,58 \pm 0,02^{* *}$ & $1,98 \pm 0,02^{* *}$ \\
\hline $\mathrm{P}$ & $2,45 \pm 0,22$ & $1,67 \pm 0,05$ & $1,68 \pm 0,10$ & $2,12 \pm 0,06^{* *}$ & $1,53 \pm 0,02^{* *}$ & $2,00 \pm 0,07^{* *}$ \\
\hline $\mathrm{Mg}$ & $0,88 \pm 0,08$ & $0,95 \pm 0,04$ & $0,92 \pm 0,05$ & $0,90 \pm 0,06$ & $1,07 \pm 0,02^{* *}$ & $0,83 \pm 0,05^{* *}$ \\
\hline
\end{tabular}

Примечание: по отношению к новорожденным * $\mathrm{p} \geq 0,05$; в остальных случаях ** $\mathrm{p} \leq 0,05$.

У телят контрольной группы по завершении молозивного периода отмечено снижение ионов натрия на $17,6 \%$, хлора на $16,6 \%$, калия на $41,7 \%$, кальция на $6,1 \%$, фосфора на $13,5 \%$.

У телят второй группы, получивших биологически активную добавку, наметилась тенденция к увеличению содержания в крови натрия, повышению хлора на 6,9 \%, кальция на $15,7 \%$, магния на $12,6 \%$ и снижение калия на $15,2 \%$ и фосфора на $8,4 \%$.

У телят третьей группы, получивших биологически активную добавку лишь в позднем антенатальном периоде, отмечена тенденция к снижению натрия, хлора и кальция, а также снижение магния на 9,8\% наряду с повышением фосфора на 19,0 \% и калия на 5,0 \%.

Известно, что дисбаланс ионов (туболопатия) в раннем постэмбриональном периоде обусловлен несовершенством структуры мембранных белков-носителей, ферментной системы, чувствительности рецепторов клеток к действию гормонов, дефицитом витаминов, и в первую очередь D. В то же время снижение фосфат-ионов в сыворотке крови обусловлено их вовлечением в процессы синтеза, фосфорилирования и дефосфорилирования промежуточных соединений. Что касается калия, то переход на экзогенное питание стимулирует функционирование гормонов, оказывающих влияние на его распределение между внутри- и внеклеточной средами и ускоряющих переход в клетки.

У телят всех группы отмечается изменение соотношения натрия и хлора, натрия и калия, калия и магния, кальция и фосфора, а именно у контрольных телят пропорция составила $1,34: 1 ; 32,0: 1 ; 3,76: 1$ и $0,91: 1$. У телят 2 группы взаимоотношение между натрием и хлором равно $1,30: 1$; натрием и калием - 29,4:1; калием и магнием $-4,39: 1$; кальцием и фосфором $-1,69: 1$, у телят 3 группы соответственно $1,39: 1 ; 23,4: 1 ; 6,96: 1$ и $0,99: 1$.

У телят контрольной группы наиболее выраженное изменение (по сравнению с первоначальными данными) произошло в соотношении натрия и калия, калия и магния; у телят второй группы отмечены сдвиги в отношении натрия и калия; калия и магния; кальция и фосфора; в третьей группе - между кальцием и фосфором.

Во всех группах телят отмечены изменения в соотношении калия и магния, что, вероятно, обусловлено нестабильностью функционирования натрий-калиевого насоса из-за истощения запасов магний-зависимой $\mathrm{Na}^{+}-\mathrm{K}^{+}$-АТФазы накапливающего ионы калия внутри клеток [5].

Заключение. У новорожденных телят опытных групп содержание в сыворотке крови ионов натрия, хлора, кальция и магния было больше, чем в контрольной группе. У телят третьей группы по сравнению с контрольной группой по завершении молозивного периода концентрация натрия, хлора и калия была выше. Пятисуточные телята второй группы по содержанию ионов натрия, хлора, кальция и магния превосходили аналогов из контрольной и третьей группы.

Полученные результаты дают основание сделать выводы о стимулирующем влиянии биологически активной добавки, содержащей низкомолекулярные пептиды, нуклеозиды и нуклеотиды, на ионный обмен; антенатальное и раннее постнатальное применение препарата способствует увеличению $\mathrm{Na}, \mathrm{Cl}, \mathrm{Ca}$ и $\mathrm{Mg}$ в сыворотке крови.

\section{Библиографический список}

1. Барышникова, Г.А. Дисбаланс электролитов и его роль в развитии сердечно-сосудистых заболеваний [Текст] / Г.А. Барышникова, С.А. Чорбинская, И.И. Степанова // Эффективная фармакотерапия. 2019. Т. 15. № 20. С. 54-60.

2. Барышникова, Г.А. Дефицит калия и магния, их роль в развитии сердечно-сосудистых заболеваний и возможность коррекции
[Текст] / Г.А. Барышникова, С.А. Чорбинская, И.И. Степанова, О.Е. Блохина // Consilium Medicum. 2019. № 21 (1). С. 67-73.

3. Белоконова, Н.А. Мониторинг состояния водного и электролитного баланса организма [Текст] / Н.А. Белоконова, Л.Г. Полушина, Р.П. Лелекова // Здоровье населения и среда обитания. 2016. № 7. С. 8-11. 
4. Былова, Н.А. Калия и магния аспарагинат в практике терапевта [Текст] / Н.А. Былова // Трудный пациент. 2013. № 1. Том 11. С. 21-24.

5. Гапонова, Н.И. Нарушения калий-магниевого гомеостаза в клинической практике: коррекция сбалансированным раствором калия и магния аспарагината [Текст] / Н.И. Гапонова, В.Р. Абдрахманов, В.А. Кадышев, А.Ю. Соколов // Лечащий врач. 2014. № 2. С. 27-30.

6. Дементьева, И.И. Исследование кислотно-основного равновесия [Текст] / И.И. Дементьева; под ред. В.В. Меньшикова // Клиническая лабораторная аналитика. М.: ЛабинформРАМЛД, 2000. Т. 3. С. 349-361.

7. Калашников, Н.П. Регуляция обмена воды и электролитов (калия, натрия и хлора) в организме телок [Текст]: автореф. дис. ... канд. биол. наук / Н.П. Калашников. Боровск, 1985. 22 с.

8. Костюченко, Л.Н. Нарушения калиймагниевого гомеостаза и его коррекция в ходе нутриционной поддержке гастроэнтерологического профиля [Текст] / Л.Н. Костюченко // Трудный пациент. 2010. № 10. Том 8. С. 40-47.

9. Методы ветеринарной клинической лабораторной диагностики [Текст]: справочник / Под ред. И.П. Кондрахина. М.: КолосС, 2004. $520 \mathrm{c}$.

10. Нормы и рационы кормления сельскохозяйственных животных [Текст]: справочное пособие. 3-е издание переработанное и дополненное / Под ред. А.П. Калашникова, В.И. Фиси- нина, В.В. Щеглова, Н.И. Клейменова. Москва: Россельхозакадемия, 2003. 456 с.

11. Синельщикова, Д.И. Диагностика ионного статуса и биохимических показателей крови высокопродуктивных стельных сухостойных коров АО «Вергуза» [Текст] / Д.И. Синельщикова, Л.В. Клетикова, А.Н. Мартынов // Аграрная наука в условиях модернизации и инновационного развития АПК России. Сборник материалов Всероссийской научно-методической конференции с международным участием, посвященной 100-летию высшего аграрного образования в Ивановской области (28-29 ноября 2019, Иваново). Иваново: Ивановская ГСХА, 2018. C. 502-505.

12. Тимофеева, А.А. Физиологическое значение хлора в организме [Электронный ресурс] / А.А. Тимофеева, Н.А. Любин // Концепт: научно-методический электронный журнал. 2017. T. 39. С. 361-365. Режим доступа: http:// e-koncept.ru/2017/970399.htm.

13. Трифонова, Т.А. Прикладная экология [Текст] / Т.А. Трифонова, Н.В. Селиванова, Н.В. Мищенко. М.: Академический проект; Гаудеамус, 2007. $384 \mathrm{c}$.

14. Шапиро, Я.С. Биологическая химия [Текст]: учебное пособие / Я.С. Шапиро. СПб: ЭЛБИ-СПб, 2004. С. 44-45.

15. Litvitsky P.F. Ion Exchange Disorders. Voprosy sovremennoi pediatrii - Current Pediatrics. 2015; 14 (3): 349-357.

\section{Сведения об авторах}

1. Синельщикова Дарья Ивановна, аспирант, Федеральное государственное бюджетное образовательное учреждение высшего образования «Ивановская государственная сельскохозяйственная академия имени Д.К. Беляева», 153012, г. Иваново, ул. Советская, д. 45, тел.: +7 (4932) 32-81-44, e-mail: rektorat@ivgsha.ru.

2. Клетикова Людмила Владимировна, доктор биологических наук, доцент, профессор кафедры акушерства, хирургии и незаразных болезней животных, Федеральное государственное бюджетное образовательное учреждение высшего образования «Ивановская государственная сельскохозяйственная академия имени Д.К. Беляева», 153012, г. Иваново, ул. Советская, д. 45, тел.: +7 (4932) 32-81-44, e-mail: rektorat@ivgsha.ru.

3. Мартынов Александр Николаевич, кандидат ветеринарных наук, доцент кафедры акушерства, хирургии и незаразных болезней животных, Федеральное государственное бюджетное образовательное учреждение высшего образования «Ивановская государственная сельскохозяйственная академия имени Д.К. Беляева», 153012, г. Иваново, ул. Советская, д. 45, тел.: +7 (4932) 32-81-44, e-mail: rektorat@, ivgsha.ru.

Значимым показателем в обеспечении гомеостаза является ионный состав крови. Целью исследования явилось изучение динамики ионов у телят при анте- и неонатальном применении добавки, содержащей низкомолекулярные пептиды, нуклеозиды и нуклеотиды. Определение в сыворотке крови $\mathrm{Na}, \mathrm{Cl}, \mathrm{K}, \mathrm{Ca}, \mathrm{P}, \mathrm{Mg}$ выполнено на биохимическом анализаторе BA-88A «Semiauto Chemistry Analyzer» и анализаторе электролитов i-SMART 30 Vet. В результате применения антенатальной добавки у новорожденных телят опытных групп концентрация ионов $\mathrm{Na}$, $\mathrm{Cl}, \mathrm{Ca}, \mathrm{P}, \mathrm{Mg}$ в сыворотке крови выше по сравнению с контрольными, а их соотношение отвечает физиологическим нормам. Введение добавки телятам в течение всего молозивного периода стимулировало ионный обмен, способствовало повышению энергетического потенциала и содержания $\mathrm{Na}, \mathrm{Cl}, \mathrm{K}, \mathrm{Ca}$, и $\mathrm{Mg}$. У телят, получивших добавку лишь в антенатальный период, в сыворотки крови было высокое содержание $\mathrm{K}$ и $\mathrm{P}$ на фоне снижения концентрации 
ионов $\mathrm{Na}, \mathrm{Cl}, \mathrm{Ca}$ и $\mathrm{Mg}$. У контрольной группы телят установлено снижение уровня ионов, что свидетельствует о незрелости буферных и ферментных систем, белков-носителей, чувствительности рецепторов клеток к действию гормонов, дефиците витаминов. Таким образом, антеи неонатальная профилактика, основанная на введении в течение 5 суток коровам-матерям и новорожденным телятам добавки, содержащей низкомолекулярные пептиды, нуклеозиды и нуклеотиды в дозе 0,1 г/кг живой массы, способствовала стимуляции метаболических процессов, повышению концентрации ионов в сыворотке крови, их утилизации и реутилизации.

D. Sinelshchikova, L. Kletikova, A. Martynov

ION COMPOSITION OF CALVES BLOOD

IN ANTE- AND NEONATAL INJECTION OF BIOLOGICALLY ACTIVE SUPPLEMENT

Key words: calves; homeostasis; ions; dietary supplement; antenatal and neonatal use.

\section{Authors' personal details}

1. Sinelshchikova Daria, graduate student, Ivanovo State Agricultural Academy named after D. Belyaev, 153012, Ivanovo, Sovetskaya st., 45, phone: +7 (4932) 32-81-44, e-mail: rektorat@ivgsha.ru.

2. Kletikova Lyudmila, Doctor of Biological Sciences, Associate Professor, Professor of the Department of Obstetrics, Surgery and Non-communicable Animal Diseases, Ivanovo State Agricultural Academy named after D. Belyaev, 153012, Ivanovo, Sovetskaya st., 45, phone: +7 (4932) 32-81-44, e-mail: rektorat@ivgsha.ru.

3. Martynov Alexander, Candidate of Veterinary Sciences, Associate Professor of the Department of Obstetrics, Surgery and Non-communicable Animal Diseases, Ivanovo State Agricultural Academy named after D. Belyaev, 153012, Ivanovo, Sovetskaya st., 45, phone: +7 (4932) 32-81-44, e-mail: rektorat@ivgsha.ru.

The ionic composition of the blood is important in maintaining homeostasis. The purpose of research was to study the dynamics of ions in calves in antenatal and neonatal use of supplement that contains low-molecular peptides, nucleosides and nucleotides. We used a biochemical analyzer BA88A «Semi-auto Chemistry Analyzer» and an electrolyte analyzer i-SMART 30 Vet to determine $\mathrm{Na}$, $\mathrm{Cl}, \mathrm{K}, \mathrm{Ca}, \mathrm{P}$ in blood serum. As a result of antenatal use of supplement in newborn calves of experimental groups concentration of ions $\mathrm{Na}, \mathrm{Cl}, \mathrm{Ca}, \mathrm{P}$, $\mathrm{Mg}$ in blood serum is higher than in control ones, and their ratio meets physiological standards. The use of the supplement during the entire colostrum period stimulated ion exchange, increased the energy potential and the content of $\mathrm{Na}, \mathrm{Cl}, \mathrm{K}, \mathrm{Ca}$, and
Mg. Blood serum of calves who received the supplement only in the antenatal period was characterized by a high content of $\mathrm{K}$ and $\mathrm{P}$ and the ion concentration of $\mathrm{Na}, \mathrm{Cl}, \mathrm{Ca}$ and $\mathrm{Mg}$ was decreased. The control group of calves has a decrease in the level of ions, and it indicates the immaturity of buffer and enzyme systems, proteins-carriers, the sensitivity of cell receptors to the action of hormones, and a vitamin deficiency. Thus, antenatal and neonatal prevention based on the supplement containing low molecular peptides, nucleosides and nucleotides at a dose of $0,1 \mathrm{~g} / \mathrm{kg}$ for mother cows and newborn calves within 5 days helped to stimulate metabolic processes, the concentration of ions in the blood serum was increased as well as their utilization and reutilization.

(C) Синельщикова Д.И., Клетикова Л.В., Мартынов А.Н.

УДК 636.087.7:636.5

DOI: 10.31563/1684-7628-2020-53-1-114-125

Е.Н. Сковородин, Г.В. Базекин, Г.З. Бронникова, О.В. Дюдьбин

\section{МОРФОЛОГИЧЕСКОЕ ОБОСНОВАНИЕ ПРИМЕНЕНИЯ АНТИОКСИДАНТОВ ПРИ ВЫРАЩИВАНИИ ПТИЦЫ}

Ключевые слова: гуси; утки; перепела; морфология; печень; ультраструктура; гепатоциты; антиоксиданты; селен; диизопропиламмоний дихлорацетат.

Введение. Изучение биохимических процессов в организме птиц и их морфологических проявлений способствует созданию новых видов кормов и кормовых добавок, которые мак- 